\title{
Chapter 8 \\ Imagining the Forces of Life and the Cosmos in the Kelabit Highlands, Sarawak
}

\author{
Monica Janowski
}

In this chapter I want to pose questions about how we should imagine the relationship between humans and the cosmos in which they live, drawing on data which I have gathered on indigenous ideas and beliefs about life and the meaning of being human during fieldwork over more than 20 years in the Kelabit Highlands in Borneo; and on Tim Ingold's processual approach to the nature of life. I suggest that, building on Ingold's work, we can use Kelabit ideas to encourage us to think further about the nature of individuation within a continuous flow of power and life through the cosmos.

\section{The Kelabit Highlands}

Pa' Dalih is a longhouse-based settlement of about 120 people at the headwaters of the Baram river (see Figure 8.1). The Kelabit Highlands, in which it is situated, lies at between 3,000 and 4,000 feet above sea level, abutting the border with East Kalimantan, and forms part of a large plateau in the centre of Borneo, surrounded by mountains, which is mainly over the border in East Kalimantan, Indonesia. The plateau is a fertile and relatively populated area compared to many other parts of interior Borneo. The whole of the plateau is notable for the fact that its linguistically related inhabitants ${ }^{1}$ practise wet cultivation of rice (Janowski 2004) as well as dry shifting cultivation; and for the presence of many megalithic monuments, some erected up to the 1950s (Banks 1937, Harrisson 1958, Schneeberger 1979). Both rice and megalithic monuments relate closely to the way in which the Kelabit 'imagine' the workings of the cosmos and their role in this, as I will show.

Until the 1960s, when an air service was set up to the highlands, it took many weeks by boat and then on foot to reach the area from the coast. Although there were always contacts between the highland area and the coast, these were rare. The point at which the Kelabit Highlands entered the outside world, symbolically,

1 Speaking languages belonging to the Apo Duat (more properly called Apad Uat, or 'Root Range', after the range of mountains running down the middle of the area) group of languages (Hudson 1992). 


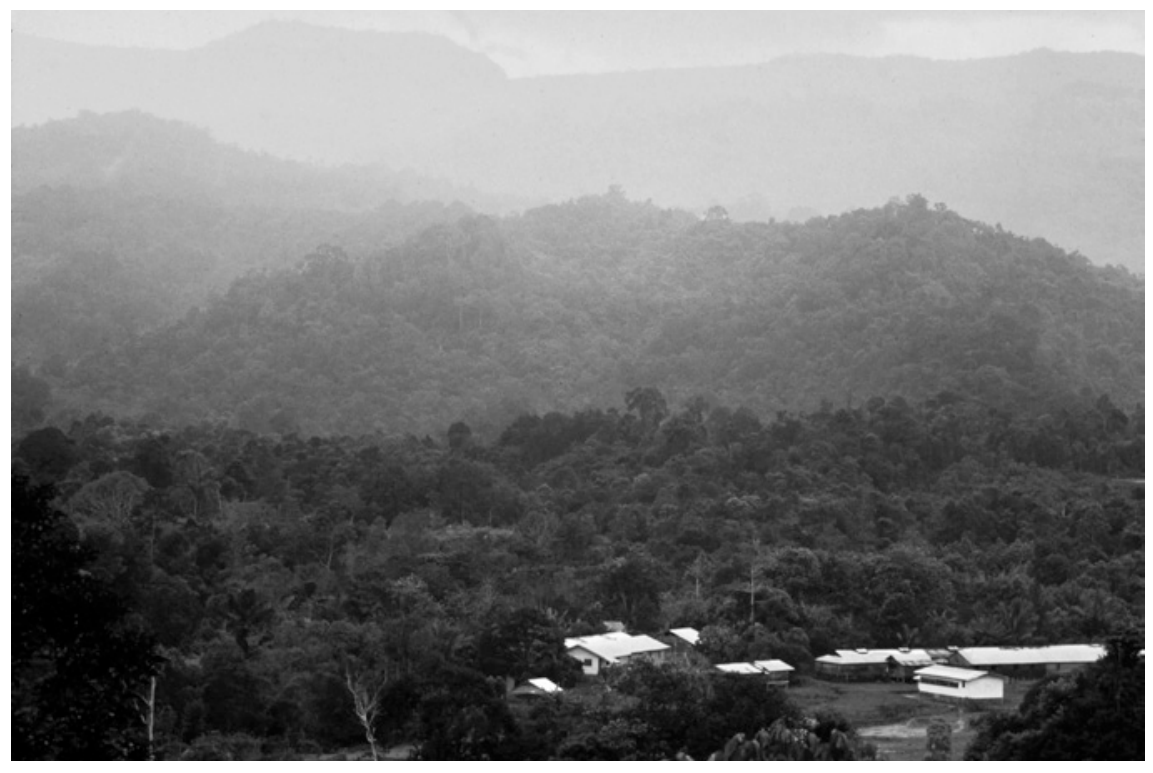

Figure 8.1 The longhouse community of Pa' Dalih, with, in the distance, a mountain ridge said to be a longhouse turned to stone (ruma batu)

Source: Image courtesy of Kaz Janowski.

may be said to be 25 March 1945, when Tom Harrisson ${ }^{2}$ was parachuted into the Kelabit Highlands as a Special Operations Executive operative, to organise resistance against the Japanese among the interior peoples. The impact of involvement in this campaign was very significant in creating a strong impetus towards the outside world and in particular towards the belief system perceived to be that of Harrisson and his European colleagues - Christianity. After the war ended, Borneo Evangelical Mission missionaries established bases and short airstrips throughout the highlands and the Kelabit showed themselves to be very willing converts to Christianity.

Little is known about the environmental or human history of the Kelabit Highlands or indeed of the interior of Borneo. Very limited written records extend back to the beginning of the twentieth century, when administrative officers of the Sarawak government made their first visits to the interior. In this context, the

2 Harrisson, who in the 1930s had led an Oxford University expedition to Borneo and participated in setting up the Mass Observation archive, went on to become an important figure in Sarawak and in relation to the Kelabit as a people after the Second World War. He became Curator of the Sarawak Museum and published a number of articles and a book on the Kelabit (Harrisson 1959). 
Cultured Rainforest project, ${ }^{3}$ which worked in the Kelabit Highlands between 2007 and 2011, brought together anthropology, archaeology and environmental history to begin to develop a picture of past and present relations between people and landscape in the highlands. The project, for which I led the anthropological work, included excavation at old settlement sites and interviews about settlement history and genealogies; excavation at megalithic cemetery sites and interviews about preChristian disposal of the dead; the taking of earth cores leading to the analysis of pollen and phytoliths, and interviews about the history of rice cultivation and attitudes to alternative starch sources such as sago palms; and the gathering of myths and stories relating to the landscape.

\section{Metaphysical Speculation among the Kelabit}

I have found that metaphysical speculation - what one might describe as 'imagining' the nature of reality and the role of human beings in it - is inherent in the way my friends and neighbours in Pa' Dalih think. Although individuals vary, it is generally not difficult to engage 'ordinary'4 Kelabit in discussions about the way the world works, and they often spontaneously offer speculation. This contrasts with the response of most 'ordinary' Europeans to being asked big questions about how the cosmos works; most feel that this is not something about which it is appropriate for them to speculate. In the main, 'ordinary' Europeans see such speculation as the business of specialists, whether priests or scientists. The Kelabit, on the other hand, see speculation about the workings of the cosmos, and - linked to such speculation - intervention on their part in these workings, as something to which all humans can and should aspire.

For the Kelabit, intervention in the workings of the cosmos is seen as an achievement, and is the basis of status. Their interest in metaphysical speculation seems to be part of a wider interest in trying out new ways of thinking and doing, and a belief that this is important in achieving their capabilities as humans (lemulun) rather than animals (poong). The Kelabit are often talked of in Sarawak, and talk of themselves, as particularly capable innovators; and they are very proud of this. They point to their rapid adoption of new techniques of rice cultivation, their success in education, and their early and eager adoption of Christianity as proof of their innovatory ability. Other tribal groups in Sarawak appear to admire and respect the Kelabit for this ability, although they sometimes criticise them for their arrogance!

3 Funded by the UK Arts and Humanities Research Council. See $<$ http://www.arch. cam.ac.uk/cultured-rainforest/>.

4 By 'ordinary' Kelabit and 'ordinary' Europeans I refer here, loosely, to people who are not educated above secondary level and who may not pretend to have specialised scientific knowledge about any aspect of the dynamics of the cosmos. 
Christianity was not forced upon the Kelabit. Following the Second World War, they invited missionaries to come and convert them. During the 1950s and 1960s, the Borneo Evangelical Mission built short airstrips throughout the Kelabit Highlands, including at $\mathrm{Pa}$ ' Dalih, and visited regularly in that period. By the early 1970s its successor the Sidang Injil Borneo or SIB (the Borneo Evangelical Church) was formed, and the foreign missionaries who led the BEM were able to leave. ${ }^{5}$ Before they were converted the Kelabit prayed to a variety of spirits or deities for success in agriculture and hunting; now the Kelabit have switched to praying to Jesus Christ. They have almost completely abandoned any interest in pre-Christian practices, believing that the new religion, and in particular Jesus Christ, provides an immensely powerful new platform from which to link directly to the Creator Deity and to manage and manipulate the cosmos. In this, they contrast with most other tribal groups in Borneo, who have also converted to Christianity or Islam but who are generally more syncretic in their approach to the new religion.

Despite the 'break with the past' which the Kelabit themselves see in their lives with the coming of Christianity, ${ }^{6}$ there are some parallels between pre-Christian and Christian belief and practice in relation to ideas about lalud. The relationship with potent entities, including both pre-Christian spirits and Jesus, is set up through prayer, now called sembahyang (using the Malay term). This is still, as it was before Christianity arrived, forest- and mountain-oriented. Although each community has a church, the Kelabit regularly pray on forested hills and mountains, and there is an annual pilgrimage to a nearby mountain which is attended by both Kelabit and related Lun Dayeh and Lun Bawang. It seems that the main difference between the two systems, in Kelabit eyes, lies in the much greater effectiveness of Christianity in terms of the ability it bestows upon them to manipulate the cosmos.

In addition, Christianity appears to have provided the Kelabit with a new platform from which to launch their thoughts about the meaning and direction of the cosmos. While linked to practice, this is also purely philosophical. Each Kelabit person has his or her own take on the workings of the cosmos and how he or she can interact with them, and most are willing to talk these through with anyone interested. Sidang Injil Borneo church orthodoxy is malleable and shifting, reflecting constant discussion among individuals. It is a charismatic and evangelical church which encourages everyone to interpret the meaning of the Bible, and this encourages high levels of philosophical speculation. The Bible can be interpreted in many ways, and is particularly mysterious in its import for peoples living in such a different cultural and environmental context from those who wrote it. There is a palpable sense of exploration and excitement among the congregation in church during sermons, which may be delivered by any member.

5 See Lees (1979) for a description of the conversion of the Kelabit.

6 This is quite explicit; for example, one of the chapters in the BA thesis written by a young Kelabit in 1976, Robert Lian-Saging, is entitled 'Break with the Past' (Lian-Saging 1976/77). 
The Bible is seen as giving important clues about how the cosmos works and how people can intervene in its workings successfully; but these are mysteriously worded, and there to be questioned and explored by all.

\section{Lalud: The Flow of Life in the Kelabit Highlands}

Although each man and woman engages in his or her own speculations, certain strong threads are common to all of my Kelabit friends. The most central of these is the concept of lalud. Lalud is akin to concepts in other parts of Southeast Asia and the Pacific, including Polynesian mana and Javanese kasekten (Anderson 1972), Balinese sakti (Geertz 1980) and Polynesian mana. It is manifest power. Lalud drives volcanoes, rivers, the rain, the sun - and, most importantly, life itself. Life is, in fact, the manifestation of lalud. Through lalud, people, plants and animals are able to live, mulun. As our friend and next door neighbour in the longhouse, Balang Pelaba ${ }^{7}$ - 'Very Much a Tiger'- said to me in 2008: 'If it weren't for lalud, you wouldn't be alive'. Where there is movement and activity, there is believed to be life and lalud.

Lalud is fundamental to the cosmos. Without it the cosmos would not exist. The Kelabit view of the cosmos is close to that which, according to Ingold, is held by peoples in many parts of the world, including Southeast Asia, for whom 'the animacy of the lifeworld ... is not the result of an infusion of spirit into substance, or of agency into materiality, but is rather ontologically prior to their differentiation' (Ingold 2006: 10). The Kelabit see lalud as concentrated in and deriving from a parallel part of the cosmos, associated with spirits ( $\left.a d a^{\prime}\right)$ and God - and nowadays with Jesus. God, Tuan Allah in Christianity, is seen as the same Creator Deity as the pre-Christian Creator Deity, known by various names. The parallel spirit part of the cosmos is invisible or only partially visible. It appears to be co-present with the material world, and $a d a$ ' are in it when they are sometimes perceived (kelit - see below) by humans. Lalud associated with the spirit world can only be expressed through the material cosmos. Thus, the material world and the force of lalud are inextricably linked. The material world is essentially a fully perceptible manifestation of the spirit world. Through the playing out of lalud the material world itself is played out.

\section{Humans and Lalud}

The parallel reality of the spirits, and of God, is only partially perceptible by humans. While it is encountered by all at some level when they are in the forest, and particularly at cemetery sites, only certain people can interact with it directly. Women, in the past, were particularly associated with one major spirit, Deraya,

7 Sadly deceased on 6 October 2009. 
associated with rice, but this appears not to have been a close personal relationship but a sense that Deraya was favourably inclined towards them. It was men who, as shamans (dayong), journeyed in trances to bring back people's spirits which had wandered into the spirit world, and certain men were sought out by and had personal dealings with the Great Spirit (Ada' Raya) of the forest, known also as Pun Tumid, 'Grandfather Heel' - thus called because, having originally been a member of a pre-human race called the Lun Rabada, he became a spirit when his feet were reversed after a rockfall damaged them (inversion is associated with the spirit world). Balang Pelaba, who lived at the next-door hearth to us in the longhouse, used to be such a shaman, and before that, when he was a young man, he had a relationship with Pun Tumid. He told me how Pun Tumid had approached him when he was a bachelor with the suggestion that they be friends, and had given him glass phials of lalud-laden liquid with which he could heal or kill. Other men also told me that they had met Pun Tumid. Balang Pelaba and the others who had met him said that they 'perceived' (kelit) the Great Spirit but did not 'see' (ne'ar) him with their eyes. They were aware of a presence and they partially knew what Pun Tumid 'looked' like; but when asked why he could not 'see' (ne'ar) him, Balang Pelaba exclaimed that he is a spirit; how could one see him? Many people have told me that they have heard Pun Tumid hunting with dogs at night; only a spirit would do this, they say, as normal people cannot see at night to hunt with dogs. He is drawn to young men, and wants to be friends with them - and give them lalud. Now, Balang Pelaba told me, he is 'lonely', since his previous friends have abandoned him, and he wanders alone through the forest.

Jesus, too, seeks humans out to give them lalud, although humans themselves have to be open to this and to seek him out too. Through Jesus, individuals are able to access high levels of lalud - much higher, they say, than they could ever hope for from spirits, even from Pun Tumid. The Kelabit believe that Jesus has bestowed on them the ability to excel in the modern world.

Lalud flows. The way in which life-force or power flows is described in the essays in the collection of articles edited by James Fox (Fox 1980). Water, and liquid in general (one term, $p a$ ', is used for both liquid and water), is associated with lalud. Lalud flows through liquid and like liquid. Deep pools of water are believed to contain powerful spirits known as menagug, related to the wider beliefs throughout the region in the powerful spirit water serpent, naga. Blood, the liquid which flows through the body, was used until the 1950s as a means of transmitting lalud: pigs were killed and their blood smeared on those who were in transition between the spirit world and the material world, such as children being initiated into human life and men who had taken dead bodies to the cemetery. Another powerful liquid, borak (rice beer), was a vital part of all human gatherings beyond the immediate family and underlined and activated the role of rice in generating human kinship (Janowski 2011).

As lalud flows, it is also seen to saturate the inhabited landscape. To an extent which has only gradually become clear to me, the Kelabit live in a landscape which is dynamically animated. People move through the landscape on the basis of 
assumptions of the presence of lalud everywhere, albeit in greater or lesser degree. This presence is to be interpreted as it manifests itself. When I walk through the landscape with a Kelabit friend, I know that I am not experiencing it in the same way as he or she is. Not only am I not aware of the history of each tree, plant and stone we pass; I am also not on the lookout for signs of lalud in those trees, plants and stones. For my Kelabit companion, on the other hand, the landscape is a field of flow for lalud, although its actual flow cannot be predicted with certainty; it must constantly be tracked and signs of the flow sought.

In flowing, lalud coalesces in certain sites. The concentration of lalud at a site expresses itself through the presence of $a d a$ ' - 'spirits' or 'souls'. The bigger and stronger the $a d a$ ' of an entity, the more lalud it has. The highest concentrations of lalud are pure ada', which cannot be 'seen' (ne'ar) with the normal eye - they can only be 'perceived' (kelit). Visibility dissipates, as it were, as lalud rises.

Lalud does not only coalesce in humans and animals; it also coalesces in entities and substances which are - in Western terms - non-living. While lalud flows through water, hardness, and especially stoniness, is associated with the coalescence of lalud. Living things, as they become older and develop stronger ada', become more stone-like and have more lalud. Big, old trees have stronger

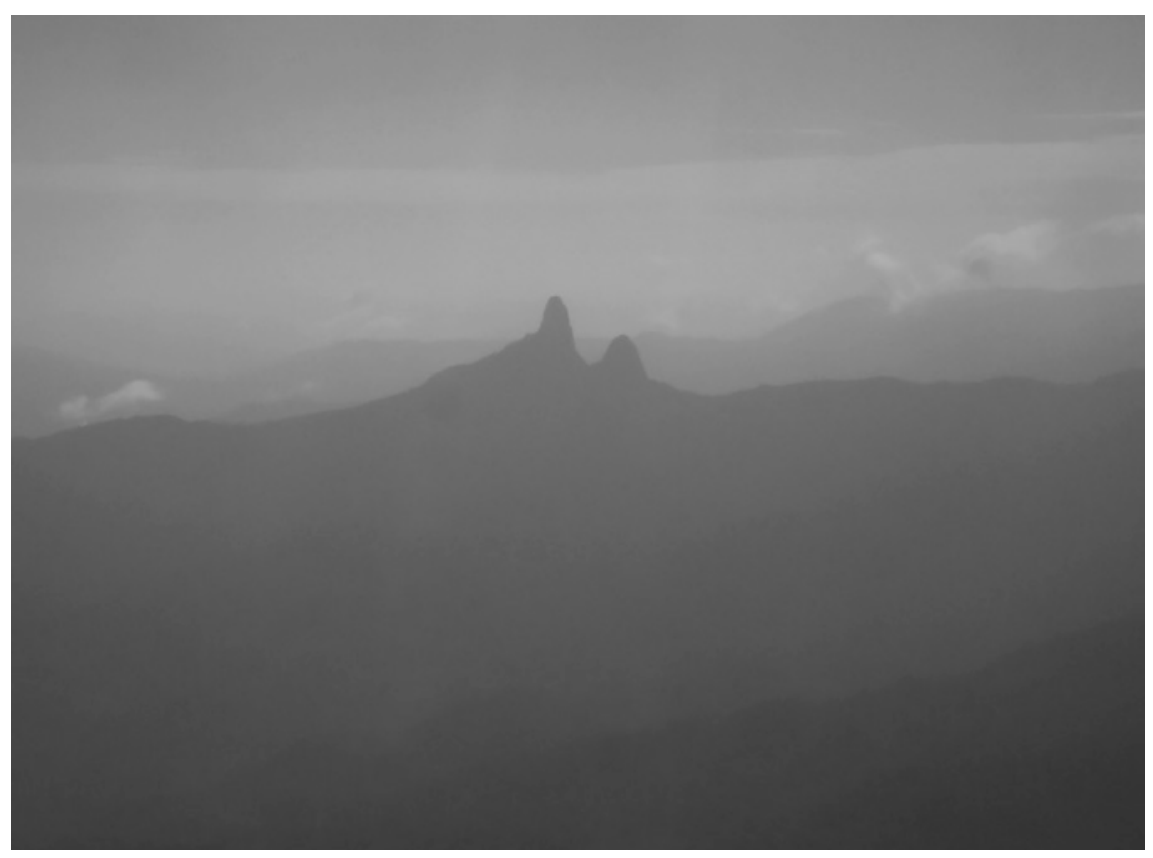

Figure 8.2 The twin stone peaks of Batu Lawi mountain, said to be male and female

Source: Image courtesy of the author. 


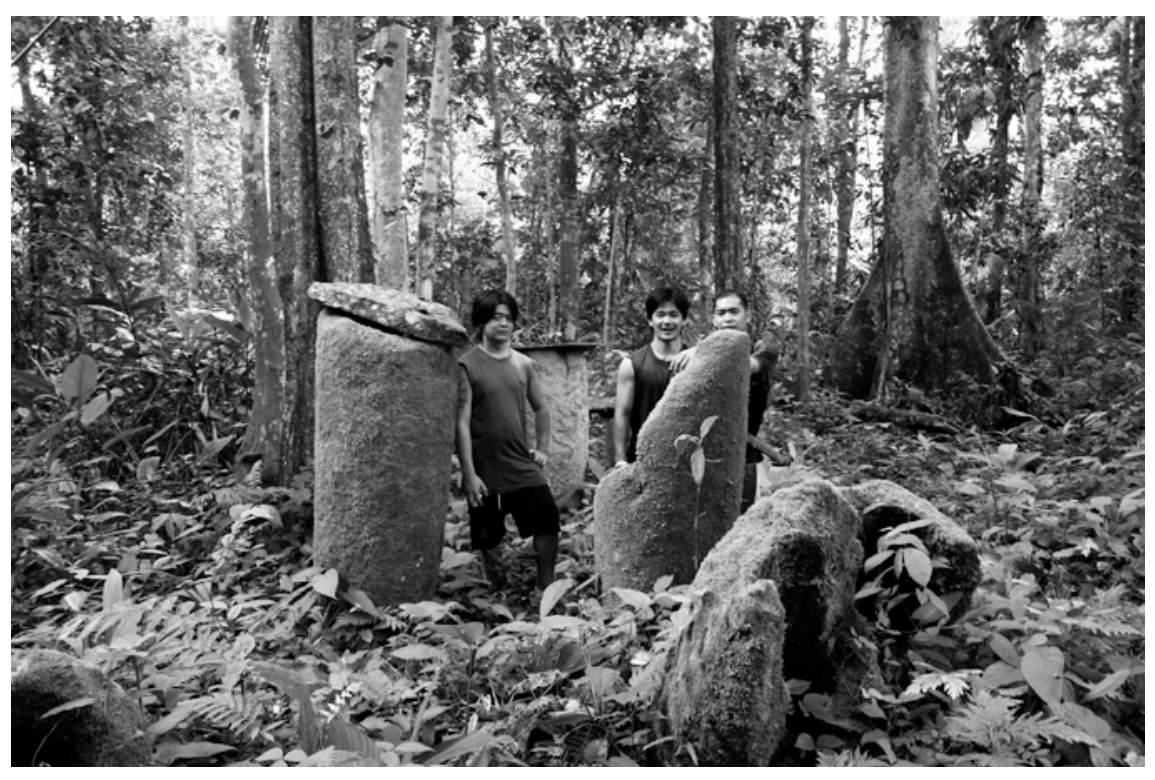

\section{Figure 8.3 Melkey, Roger and Lian of Pa' Dalih at the megalithic cemetery at Long Diit}

Source: Image courtesy of Kaz Janowski.

$a d a$ ' than young saplings. Big mountains, especially if they are made of stone like Batu Lawi (see Figure 8.2), have powerful $a d a$ '. Batu Lawi is said to be a married couple who moved around the landscape - burning places where they stopped off, which can still be identified because they are overgrown with a certain fern-laden ecology - before eventually being turned to stone. Married couples, as I have discussed elsewhere (Janowski 2007), are particularly strongly associated with lalud, being a source of it for their dependants through their focal role in the rice meal (Janowski 1995).

The transformation of Batu Lawi from human married couple to mountain is an instance of the process of balio. Balio is the transformation of a living entity from one form to another. Animals may become human or humans may become animals; and animals or humans may become spirits ( $a d a$ '). People and animals may also become stone. The most common reason for petrification is when people have laughed at animals. This leads to thunder, lightning and the descent of 'stone rain', udan batu (hail) and eventually the transformation (balio) of the person and (usually) the whole house in which he or she lives into stone. Many large stone features of the landscape are said to be houses which have been transformed into stone (see Figure 8.1). Balio is said to spread across the landscape as though it were water flowing, turning everything in its path to stone. 
Bones are strongly associated with stone: this is underlined by the fact that in the past human bones were placed in stone burial jars or within stone cists (see Figure 8.3). Bones are considered to be repositories of lalud deriving from the living entity for which they once provided a structure. The bones of ancestors carry those ancestors' lalud. The lalud of groups of ancestors should be together; thus, their bones are placed together in the same cemetery and, until the 1950s when people stopped using megalithic cemeteries, often in the same stone jar or under the same stone cist.

The jars and cists in megalithic cemeteries are believed to have been made by ancestors living in the origin time of getoman lalud, 'joining with lalud'. The Kelabit say that in the past there was much more lalud in the world, and living beings could do things they cannot do now. The culture heroes living in getoman lalud, like Tukad Rini (Janowski, forthcoming), are said to have been giants (see Figure 8.4). Tukad Rini left marks on stone with his hands and feet (see Figure 8.5 ), and is said to have been able to fly; he is said to have flown to the moon.

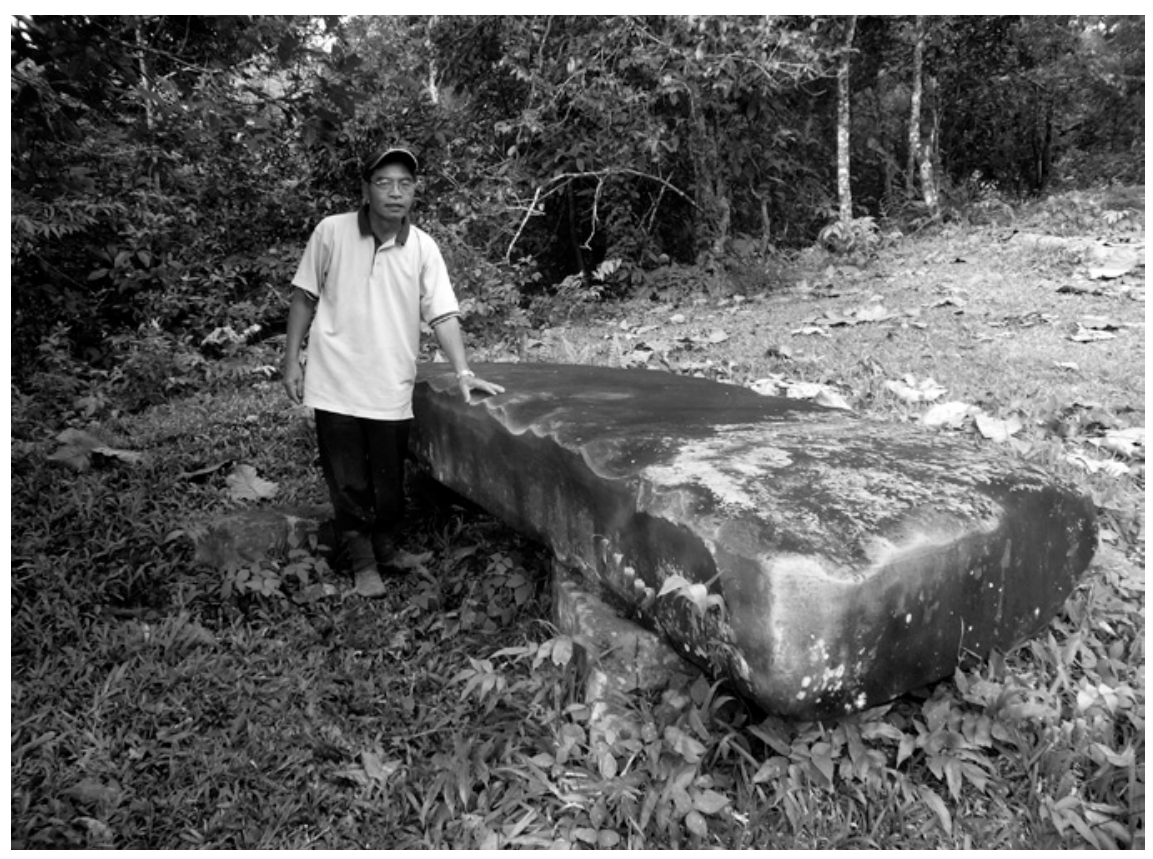

Figure 8.4 Baye Ribuh of Pa' Dalih by the giant 'sharpening stone' of the culture hero Tukad Rini

Source: Image courtesy of the author. 


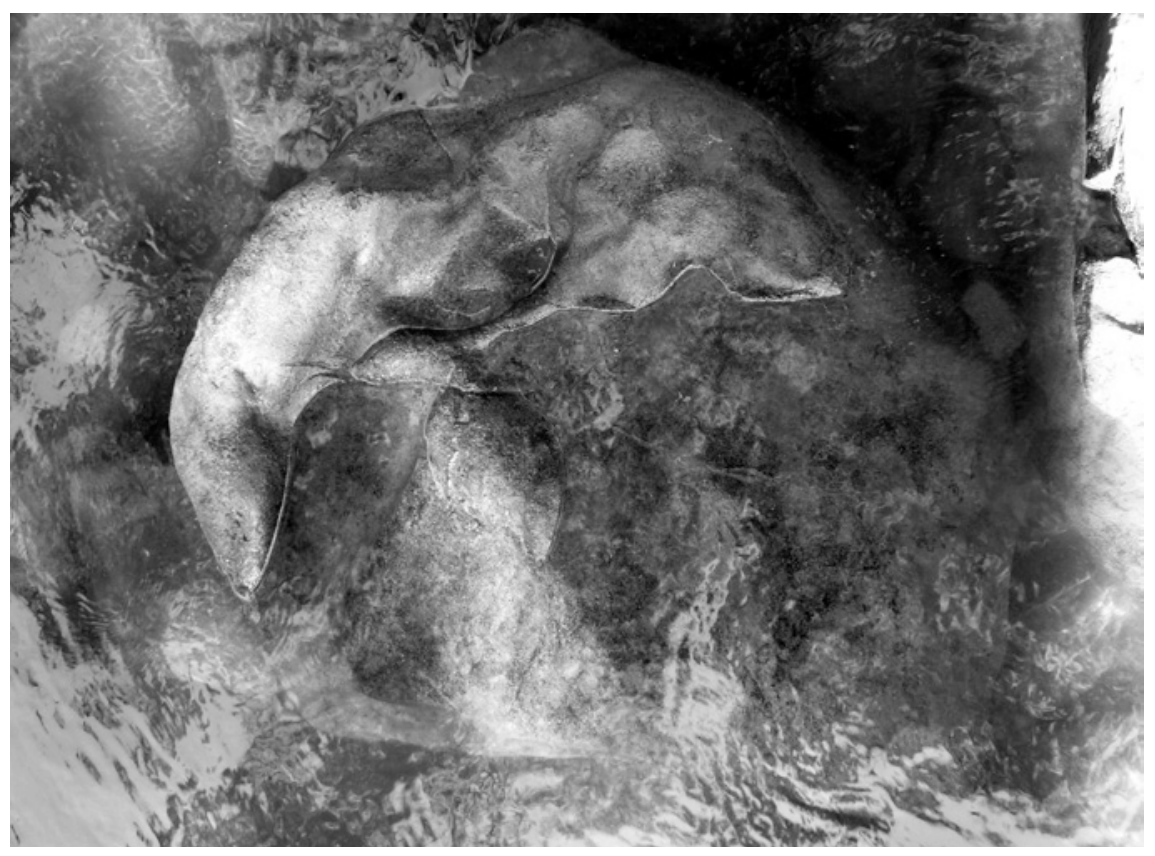

Figure 8.5 A 'footprint' said to have been made by the culture hero Tukad Rini on a stone in the Kelapang river

Source: Image courtesy of Kaz Janowski.

Lalud settles in hard objects, and these are believed to be 'alive' and to be repositories of life which is accessible to humans. This is expressed in the preChristian practice of collecting, keeping, feeding and regarding as a source of power any strange hard objects which are found in the landscape. Many people, particularly men, used to have collections of hard objects which they had found in the landscape, such as strange-shaped stones, deer's antlers or crystals, which were considered to be repositories of lalud which could be accessed and used by their owners. Such objects had to be fed blood or else they would consume their owner; thus they were regarded as both living and dangerous. Some men still maintain collections of these objects, although they say that they no longer feed them or use them to access lalud (see Figure 8.6). One of the most common kinds of objects kept in this way comprised what are called 'thunderstones' - batu pera'it. These objects are believed by both the Kelabit and by their neighbours, the hunter-gatherer Penan, to represent the coalesced and petrified form which the lalud of thunder and lightning takes upon reaching the earth (see Figure 


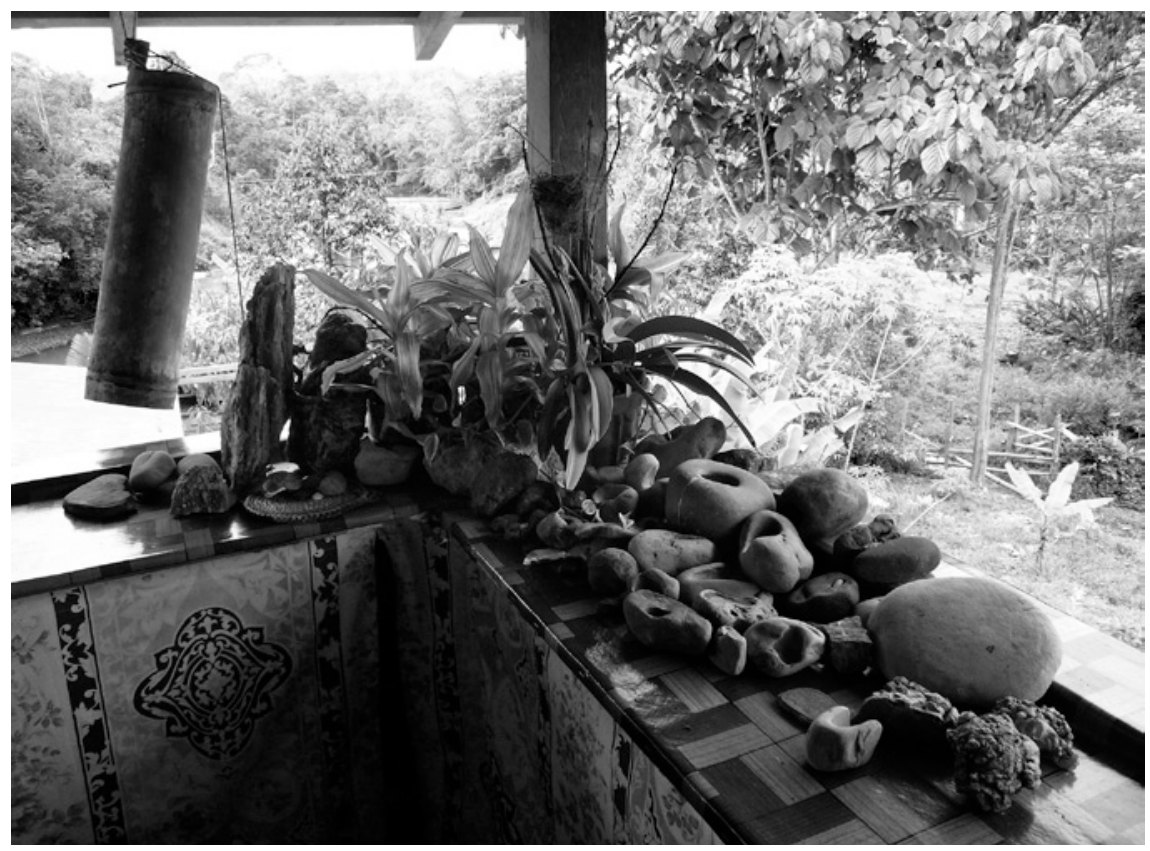

Figure 8.6 A collection of hard objects from the forest collected by Telona Bala of Pa' Dalih

Source: Image courtesy of the author.

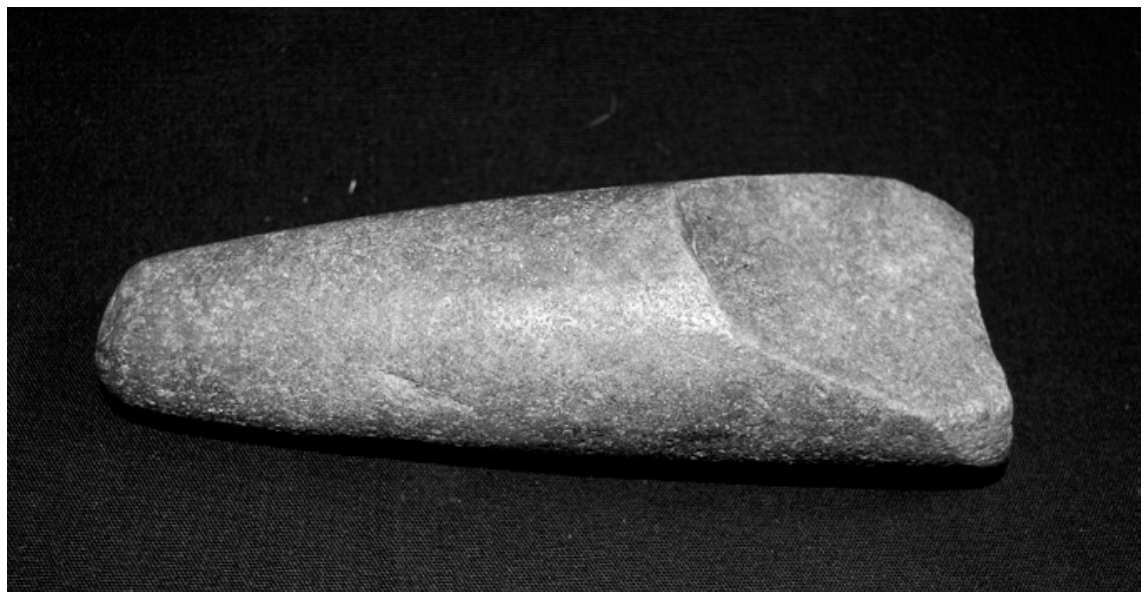

Figure 8.7 A 'thunderstone' (batu pera'it), once kept in a rice barn in Pa' Dalih

Source: (C) Trustees of the British Museum. 
8.7). ${ }^{8}$ They were kept by the Kelabit in rice barns in pre-Christian times, until the 1950 s, because they were believed to increase the amount of rice stored there.

\section{Marking the Landscape}

I have discussed elsewhere (Janowski 2007) how Kelabit married couples harness lalud through bringing wild plants and meat together with rice to generate a way of living life which is distinctive to human beings. Through the rice meal, lalud from wild animals and plants is harnessed with the structuring capacity of rice, and transmitted to those dependent on the couple providing the meal (see Janowski 1995). I have also argued that this is the foundation for a form of social hierarchy founded in inter-generational kin relations. Hierarchy is, in fact, basic to ulun.

The achievement of harnessing and transmitting lalud is marked on the physical landscape. One way of doing this is through the creation of rice fields themselves, both dry fields and wet fields but particularly wet fields. Kelabit dry rice fields are described as late luun, or 'field for growing rice on the surface'. They are used not only for growing rice but for a wide variety of other plants, including fruit trees, plants which are eaten as accompaniments to rice at the rice meal, and grains or roots which are eaten as snacks or, before the Kelabit became Christian, used to make beer. Although they are normally only used for one year for growing rice, they are used over many years for other crops, and therefore have a long-term impact on the environment and on ties between people and the environment. Wet rice fields are known as late baa, or 'wet field for growing rice'. Nowadays, these are very similar to the sawah of the lowland areas of Java and other Indonesian islands, but they appear until the 1960s to have been quite variable in their structure and use. Some seem to have been used over long periods of time, while others were used for a few years and then moved. Some were made in extended stream beds and palaeo-channels of the river, others in flooded marshy areas. The Cultured Rainforest project has found evidence of a very long history for growing rice in palaeo-channels of the river Kelapang near Pa' Dalih, possibly going back several thousand years. However, the largest and most highly developed late baa in recent times appear not to have been in the Kelabit Highlands but in the part of the plateau across the border in East Kalimantan, in the Kerayan river area (Schneeberger 1979, Padoch 1983). Here, terracing was carried out and very extensive permanent late baa existed when Schneeberger visited the area in the 1930s. In the Kelabit Highlands it is only in recent years, since the 1960s, that large-scale earthworks were carried out to create large and permanent late baa. However, even before this, earthworks were carried out to create irrigation and

8 We now know that such stones were once sago-pounders; one of the investigators on the Cultured Rainforest project, Huw Barton, has found traces of starch from a variety of local sago-bearing palms on them (see Barton and Janowski, forthcoming). 
drainage ditches, and, according to a number of my informants, also to create late baa through the encouragement of oxbow lakes.

An earthwork built to make or extend late baa is described as a form of 'mark' or etuu. Other marks were made by setting up standing stones, carving stones (see Figure 8.8), digging ditches on ridges (often to create a new path) and removing trees at a point on a ridge. Such marks were made, until the 1960s, at irau ate

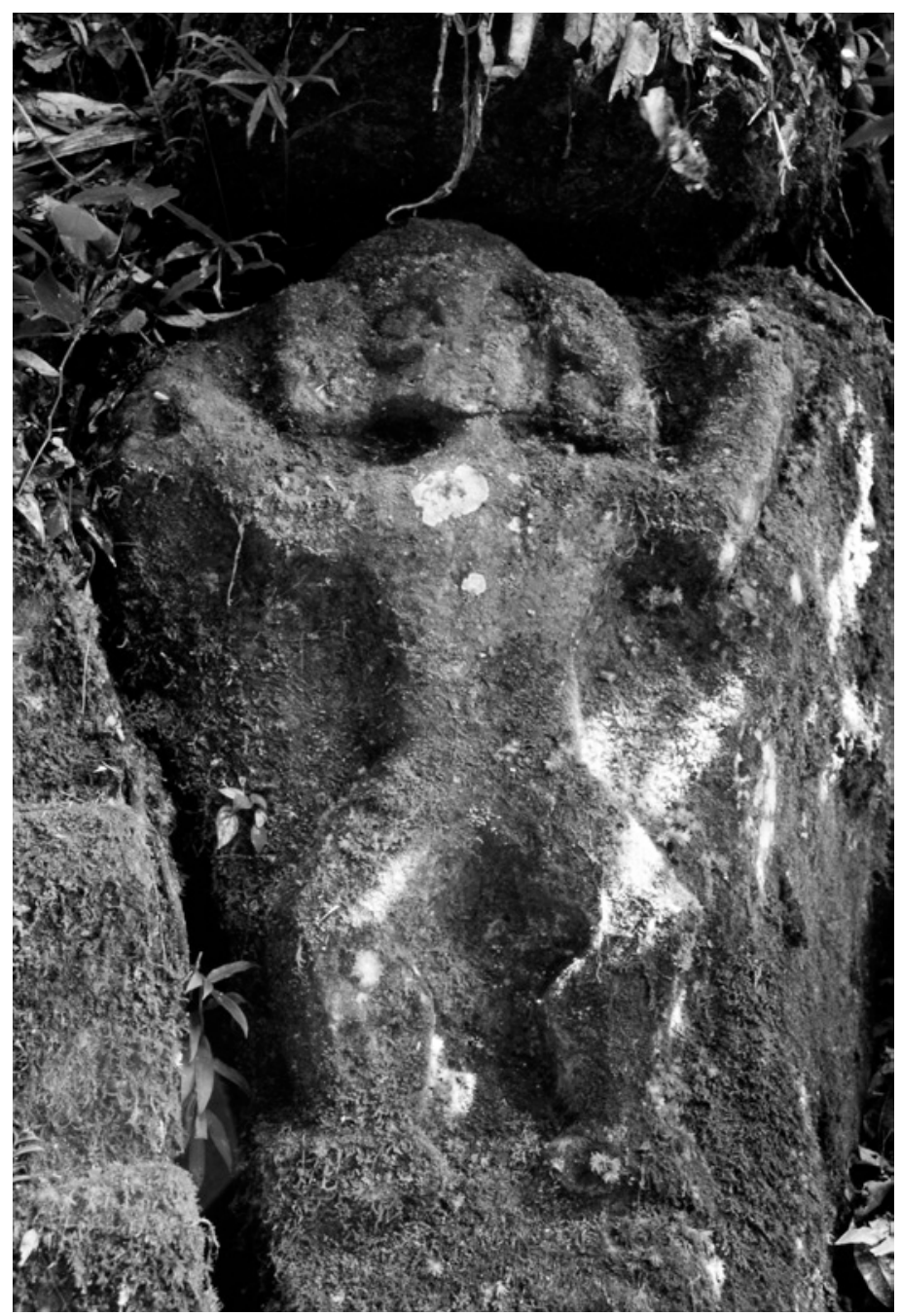

Figure 8.8 A carved stone (batu narit) near the abandoned Kelabit settlement of Pa' Bengar, said to have been made at an irau feast in the past 
('death irau'), which were occasions for broadcasting the ability of the dead person and his or her heirs - who provide the irau - to feed many people. Those who are fed are presented at the irau as his or her descendants as well as dependants. This is so because kinship, as I have shown elsewhere, is constructed through the rice meal, of which an irau is an expanded version (Janowski 1995).

The ability to feed others is proclaimed through the making of etuu marks. In the case of earthworks to facilitate rice-growing, this would contribute directly to that continuing ability. In the case of marks made at irau feasts, a lasting record of the ability to feed others is created. The size and scale of the mark reflects the number of guests at the feast; the aim is to make a statement about the ability to feed as many people as possible.

\section{Interrupting and Channelling Lalud}

Making earthworks and erecting and working stone involve taking a hand in the creation of the animated landscape. They are expressions of the ability to interrupt and channel lalud, proven through the ability to feed others. Doing these things is an expression of the way of life described as ulun, a way of life which is distinctively human. There is a distinction between just being alive - mulun - and having ulun; while all living entities live, mulun, only humans are described as having ulun.

The ability to interrupt and channel lalud is something which those with stronger ties to the spirit world and to ancestors are believed to have in greater measure than others. Higher status people are at the centre of centripetal genealogies into which all others tie themselves. These link back to powerful ancestors (Janowski 2007). The even more powerful ancestors who lived at the time of 'joining with great power' (getoman lalud) are believed to have taken an even greater hand in this creative process.

It is the Kelabit view that in order to establish rights over a landscape it is essential to show evidence, through making etuu marks, of having been instrumental in this creative process of interrupting and channelling lalud; they argue that the lack of such evidence of etuu marks on the part of the hunter-gatherer Penan who are their neighbours is grounds for arguing that the Penan should not have rights over that landscape (Janowski and Langub 2011). A successful human, of high status, should demonstrate the ability to manage and manipulate lalud effectively, and this should be visible through the etuu marks he or she makes on the landscape. This remains as true now as it was before the Kelabit became Christian, and is expressed in the large numbers of new wet rice fields which have been constructed since the 1960s in Pa' Dalih (Janowski 1988, 2004). With the coming of logging to the highlands, debates about the significance of etuu have taken on a particular significance, since they bear on questions of whether Kelabit or Penan have the right to receive compensation. 


\section{Individuation in a Holistic Field of Flow}

The Kelabit notion of the cosmos is a holistic one. For my Kelabit friends, all forces in the universe are reducible to one: lalud. Lalud drives life; and it is the fundamental cosmic force. In their view it is because of the western world's early adoption of Christianity that scientists, raised in this world and with a consequently enhanced ability to manipulate this fundamental force, have been able to perform such marvels as harnessing of the power of the atom. It was Christianity, they say, that granted science the ability to harness the lalud of the cosmos to a heightened degree. Likewise, the Kelabit attribute their own success in the modern world to their adoption of Christianity. Thus modern science, from their perspective, has not introduced a move away from a holistic notion of the workings of the cosmos. It has rather underlined this holism. Life for them is what lalud is all about; they say that the power which is harnessed through science is the same as that which makes life tick.

This contrasts with the approach taken by the majority of western-trained physicists and cosmologists, for whom understanding the cosmos does not depend on understanding life. Arguably, however, life should not be treated as an extraneous force which intervened at some unknown point in the development of the cosmos, but should rather be seen as inherent in it (Ingold 2008). The physicist David Bohm has suggested that both inanimate matter and life can be comprehended on the common ground of what he calls the 'implicate order' (Bohm 1980: 193-213). Most physicists, however, have tended to ignore life in their quest to understand the universe in a unified way.

Ingold has demonstrated the importance of taking seriously the cosmologies and philosophical musings of non-Western peoples. He has also argued for the need to reconsider the nature of life itself, focusing in his recent work (Ingold 2011) on its processual and interactive nature. Building on the writings of such philosophers as Bergson (1911), Heidegger (1971) and more recently Deleuze and Guattari (1983, 2004), Ingold has argued that life should not be seen as a fixed, internal property of mobile entities but that it is rather defined by movement (Ingold 2008, 2010). The centrality of movement to understanding the nature of living entities and of consciousness within the cosmos has also been stressed by the philosopher Sheets-Johnstone (1998). The implication of an approach to life which sees living entities not as inserted into the world, but rather as continually coming into being within it, is that the boundaries between entities are in some sense illusory; life is a continuous 'meshwork', in which materials are woven together.

This analysis fits well with Kelabit ideas about the flow of lalud. It also fits with the holistic nature of the Kelabit contention that the material world and lalud itself are one and the same: two sides of the same coin; neither able to exist without the other. For the Kelabit, all matter contains lalud; indeed, perhaps, is lalud. In some senses, this echoes the equivalence of mass and energy proposed by modern physics - except for the exclusion of life. 
Kelabit imagine that people - and other living entities - live within the flow of lalud. They are certainly part of it. However, they do not simply float along, acquiescing in a flow which takes place around them and through them. As we have seen, they both participate in the creation of this flow and actively divert it. This involves interaction and engagement with other living entities within the field of flow in which they live, including other humans, animals, trees and stones; all of them considered to be living. In some sense, then, the continuous field of flow of life is made up of distinct entities.

Kelabit conceive of humans interacting with other entities in two ways (Janowski and Langub 2011). One is through the trails or footprints which they leave. The hunter-gatherer Penan, who leave such trails, call them oban. Oban may be seen as a record of the ways in which living entities bump into, alter and divert each other - 'entangle' with each other, to use Ingold's term - in their journeyings through the cosmos. Another way in which the Kelabit - but not the Penan - relate to other entities within the animated cosmos is through the making of etuu marks, discussed above. It is these that most clearly express the Kelabit belief that it is possible to deliberately channel and manipulate the flow of life. Etuu are deliberate inscriptions. Parallels with this kind of deliberate inscription on the cosmos can be found in many societies across the globe. Ingold and Vergunst have discussed how, in the history of colonialism, humans have aimed to place their 'stamps' on the world as an index of possession (Ingold and Vergunst 2008); the impetus to create etuu might be seen as carrying something of the same force.

\section{Distinctness and Directionality within a Field of Flow}

The differentiation between those who are successful manipulators of lalud and those who are less successful, marked through etuu-making, implies the distinctness of the individual entities making the marks. Indeed, for the Kelabit distinctness is - by implication, if not explicitly - a function of life. All beings considered to be alive, to have lalud - including stones and mountains - have their own distinct trajectories. They interact and affect each other as distinct entities. It is the distinctness of living things that draws together and organises matter.

If distinctness is what organises matter into living entities, consciousness and direction on the part of living entities are, for the Kelabit, what drives the world forward. The interactions of living entities are not random; they are the result of myriad decisions and micro-decisions. Consciousness and direction, then, are also functions of life. The clearest example of this is the making of etuu, which broadcast the distinctness and differentiation both between different humans and between humans and other living entities which do not make etuu.

Thus the Kelabit not only see the entire cosmos as a field of flow for lalud; they also see themselves as part of a world that is continually in formation. At the same time they assert that life is conscious and individuated. It is through the existence of individuated conscious entities that life, for the Kelabit, has 'direction'. They 
see living entities as constantly forming and dissipating, as life coheres and accumulates at sites. As living entities become more powerful accumulations of lalud, they develop greater power to consciously 'direct' the lalud which they possess. Humans, as powerful centres at which lalud accumulates, are particularly able to manipulate and direct lalud. They remain, at the same time, part of a continual field of flow of life.

Modern biology, too, seeks to identify distinct living entities: individual members of a species. As Ingold has pointed out, modern science sees such organisms as 'discrete, pre-specified entit[ies]' (Ingold 2004: 219), entering into the world with an underlying script for their development already written before their lives begin. He criticises this approach, pointing out that it is only through their interaction with the world that living entities come into being, and that each living entity should rather be seen as 'a particular locus of growth and development within a continuous field of relationships'. This is indeed much closer to the way in which the Kelabit see things.

The Kelabit approach to the flow of life and the nature of individuation raises philosophical questions about the role of individuation and of distinct living entities or organisms within the field of flow of life. These questions are also raised, for me, by Ingold's emphasis on life as a continuous meshwork without boundaries between entities (Ingold 2006; 2008) and at the same time as concentrated in distinct organism-persons within that meshwork (Ingold 2009). What is the role of individuation within the meshwork of life? For my friends in Pa' Dalih, the 'meshwork' or flow of life could not, in fact, exist unless it were directed by the individual accumulations of lalud which are living entities. It is through these that life has existence. Living entities, for the Kelabit, are by their very essence conscious, have mind; as they become more powerful cohesions of lalud this becomes more and more evident. Because all matter contains lalud, it follows that it has the rudiments of mind and consciousness; entities which are greater accretions of lalud simply have more mind, more consciousness. Spirits have the highest levels of lalud; but humans can also be very powerful, very lalud-laden. This is expressed and proven through altering the landscape, through making etuu marks.

\section{Conclusion}

The Kelabit of Sarawak, probably in common with all other peoples not living (at least until recently) within broader political, institutional and religious structures which present them with orthodoxies ready-made, have a strong inclination towards philosophical speculation. This is a function both of practicality (they need to interact effectively with the world around them and for this they need a philosophical basis) and, arguably, of a quite general desire to comprehend the world in which they live. There is a good deal of variation in the ways in which individual Kelabit see the workings of the cosmos, but they are agreed in viewing 
these in a holistic way, and as driven by a unitary force which they call lalud. Lalud links the material and the unseen (or only partially perceptible) elements of the cosmos, which are two sides of the same coin. It flows through the material and the veiled parts of the cosmos. It coheres in certain sites, which are living entities. The presence of lalud is expressed through life; indeed, lalud and life cannot be disentangled. Living entities - cohesions of lalud - include humans, animals and plants; but they also include mountains and stones.

The Kelabit understanding of the nature of life and its relationship to the material world accords well with a focus on life as processual and in constant movement, as recently underlined by Ingold. However, the Kelabit also lay great emphasis on the way in which life coheres into distinct individuated entities, which have consciousness and directionality within the broader field of flow. Consciousness is an integral part of life; and living entities take a conscious hand in manipulating and managing the flow of life through them and other living entities. For the Kelabit, it is important to manipulate and manage the flow of lalud. The more a living entity is able to focus, manipulate and manage lalud, the more it shows itself to be a cohesion of lalud. This is expressed, at a human level, through the growing of rice and the feeding of rice meals from senior to junior kin, who are related as persons of higher and lower status. The Kelabit attitude to the Penan (Janowski 1997) emphasises the need for them to settle and grow rice. This expresses what they consider to be a benevolent desire to enable the Penan to become greater managers and manipulators of lalud, and to develop higher status.

Deleuze and Guattari (1983) have used the image of the rhizome, and Ingold (2003) that of the fungal mycelium - 'an ever-ramifying bundle of lines of growth' (Ingold 2008: 1807) - as ways of thinking about the nature of living entities in the context of an understanding of life and the cosmos as processual, flowing and constantly coming into being. Perhaps, building on this, Kelabit philosophical musings may help us, since they raise the question of directionality and encourage us to think further about this. For the Kelabit, living entities are part of a field of flow; within this, however, they are not only individuated but their individuation is inseparable from their role as direction-makers for the broader flow. The straightening of crooked rivers by leading Kelabit in the past is a metaphor for a broader cosmological role. The Kelabit view is that humans, like all living entities, are able to direct the flow of life of which they are part. By contrast to the Penan hunter-gatherers who live adjacent to them, the Kelabit add a further contention: that humans ought to take on a leading role in directing the flow of life if they are to fulfil their destiny. Why this should be regarded - not only by the Kelabit, but arguably by humans in a wide range of societies - as human destiny is another important question, which I cannot begin to address here. 


\section{Acknowledgements}

I would like to thank the people of the Kelabit Highlands, particularly of the community of Pa' Dalih. I would also like to thank the UK Economic and Social Research Council, which funded my initial PhD fieldwork in 1986-88, and the British Academy and the UK Arts and Humanities Research Council, which have funded subsequent periods of fieldwork.

\section{References}

Anderson, B. 1972. Power, in Culture and Politics in Indonesia, edited by R. Benedict, C. Holt, O.G. Anderson and J. Siegel. Ithaca: Cornell University Press. 17-77.

Banks, E. 1937. Some Megalithic Remains from the Kelabit Country in Sarawak with Some Notes on the Kelabits themselves. Sarawak Museum Journal, 4, 411-37.

Barton, H. and Janowski, M. forthcoming. Reading Human Activity in the Landscape: Stone and Thunderstones in the Kelabit Highlands. Indonesia and the Malay World.

Bergson, H. 1911. Creative Evolution. London: Macmillan.

Bohm, D. 1980. Wholeness and the Implicate Order. London: Routledge and Kegan Paul.

Deleuze, G. and Guattari, F. 1983. On the Line. New York: Semiotext(e).

Deleuze, G. and Guattari, F. 2004. A Thousand Plateaus: Capitalism and Schizophrenia, trans. B. Massumi. London: Continuum [originally published as Mille Plateaux, vol. 2 of Capitalisme et Schizophrénie, Paris: Minuit, 1980].

Fox, J.J. (ed.) 1980. The Flow of Life: Essays on Eastern Indonesia. Harvard Studies in Cultural Anthropology. Cambridge, MA and London: Harvard University Press.

Geertz, C. 1980. Negara. Princeton: Princeton University Press.

Harrisson, T. 1958. A living Megalithic in upland Borneo. Sarawak Museum Journal, VIII, 694-702.

Harrisson, T. 1959. World Within. London: The Cresset Press.

Heidegger, M. 1971. Poetry, Language, Thought. New York: Harper and Row.

Hudson, A.B. 1992. Linguistic Relations among Bornean Peoples with Special Reference to Sarawak: An Interim Report, in Shifting Patterns of Language Use in Borneo. Papers from the Second Bi-Ennial International Conference, Kota Kinabalu, Sabah, July 1992, edited by P.W. Martin. Williamsburg: Borneo Research Council.

Ingold, T. 2003. Two Reflections on Ecological Knowledge, in Nature Knowledge: Ethnoscience, Cognition, Identity, edited by G. Sanga and G. Ortalli. New York: Berghahn, 301-11. 
Ingold, T. 2004. Beyond Biology and Culture. The Meaning of Evolution in a Relational World. Social Anthropology, 12(2), 209-21.

Ingold, T. 2006. Rethinking the Animate, Re-animating Thought. Ethnos, 71(1), 9-20.

Ingold, T. 2007. Earth, Sky, Wind, and Weather. Journal of the Royal Anthropological Institute, 13(1), 19-38.

Ingold, T. 2008. Bindings against Boundaries: Entanglements of Life in an Open World. Environment and Planning A, 40, 1796-810.

Ingold, T. 2009. The Trouble with 'Evolutionary Biology'. Anthropology Today, 23(2), 13-17.

Ingold, T. 2010. Footprints through the Weather-World: Walking, Breathing, Knowing. Journal of the Royal Anthropological Institute, 16, 121-39.

Ingold, T. 2011. Being Alive: Essays on Movement, Knowledge and Description. London: Routledge.

Ingold, T. and Vergunst, J.L. 2008. Introduction, in Ways of Walking, edited by T. Ingold and J.L. Vergunst. London: Ashgate, 1-19.

Janowski, M. 1988. The Motivating Forces behind Changes in the Wet Rice Agricultural System in the Kelabit Highlands. Sarawak Gazette, CXIV(1504), 9-20.

Janowski, M. 1997. The Kelabit Attitude to the Penan: Forever children. La Ricerca Folklorica, 34, 55-8.

Janowski, M. 2004. The Wet and the Dry: The Development of Rice Growing in the Kelabit Highlands, Sarawak, in Smallholders and Stockbreeders. Histories of Foodcrop and Livestock Farming in Southeast Asia, edited by P. Boomgard and D. Henley. Leiden: KITLV, 139-62.

Janowski, M. 1995. The Hearth-Group, the Conjugal Couple and the Symbolism of the Rice Meal among the Kelabit of Sarawak, in About the House: LeviStrauss and Beyond. J. Carsten and S. Hugh-Jones. Cambridge: Cambridge University Press: 84-104.

Janowski, M. 2007. Being 'Big', Being 'Good': Feeding, Kinship, Potency and Status among the Kelabit of Sarawak, in Kinship and Food in Southeast Asia, edited by M. Janowski and F. Kerlogue. Copenhagen: NIAS Press, 93-120.

Janowski, M. 2011. Rice Beer and Social Cohesion in the Kelabit Highlands, Sarawak, in Liquid Bread: Beer and Brewing in Cross-Cultural Perspective, edited by W. Schiefenhovel and H. Macbeth. Oxford and New York: Berghahn, 183-95.

Janowski, M. forthcoming. Tukad Rini: Cosmic Traveller from the Heart of Borneo. Kuching: Sarawak Museum.

Janowski, M. and Langub, L. 2011. Marks and Footprints in the Forest: The Kelabit and the Penan of Borneo, in Why Cultivate? Anthropological and Archaeological Approaches to Foraging-Farming Transitions in Southeast Asia, edited by G. Barker and M. Janowski. Cambridge: McDonald Institute for Archaeological Research, 121-32. 
Lees, S. 1979. Drunk before Dawn. Sevenoaks, Kent: Overseas Missionary Fellowship.

Lian-Saging, R. 1976/77. An Ethno-History of the Kelabit Tribe of Sarawak. A Brief Look at the Kelabit Tribe before World War II and after. Graduation Exercise Submitted in Partial Fulfilment of the Requirements for the Degree of Bachelor of Arts, Hons., Jabatan Sejarah, University of Malaya, Kuala Lumpur.

Padoch, C. 1983. Agricultural Practices of the Kerayan Lun Dayeh. Borneo Research Bulletin, 15(1), 33-8.

Schneeberger, W.F. 1979. Contributions to the Ethnology of Central Northeast Borneo. Berne: Institute of Ethnology, University of Berne.

Sheets-Johnstone, M. 1998. The Primacy of Movement. Amsterdam: John Benjamins Publishing Company. 
